\title{
O RECONHECIMENTO CRIMINAL DE PESSOA A PARTIR DE VÍDEO DE VIGILÂNCIA ${ }^{1}$
}

\section{EYEWITNESS IDENTIFICATION FROM SURVEILLANCE VIDEO}

Clarissa Diniz Guedes Doutora em Direito Processual pela USP. Professora Adjunta da Universidade Federal de Juiz de Fora. Vice-coordenadora do Mestrado em Direito e Inovação da Universidade Federal de Juiz de Fora. Juiz de Fora/MG. Orcid: https://orcid.org/0000-0002-5490-8714. E-mail: clarissadinizguedes@gmail.com.

Giulia Alves Fardim Professora substituta da Universidade Federal de Juiz de Fora. Mestra em Direito e Inovação pela Universidade Federal de Juiz de Fora. Juiz de Fora/MG. Orcid: https://orcid.org/00000002-3517-6116. E-mail: giuliafardim@ outlook.com.

Vicente Riccio Doutor em Doutor em Sociologia pelo Instituto Universitário de Pesquisas do Rio de Janeiro (IUPERJ).Suas áreas de pesquisa são: mídia e direito, cultura jurídica, segurança pública, polícia e sociedade. Professor Associado I Universidade Federal de Juiz de Fora. Coordenador do Mestrado em Direito e Inovação. Juiz de Fora/MG. Orcid: https://orcid.org/0000-0003-1673-4335.

\footnotetext{
${ }^{1}$ Artigo recebido em 11/06/2021 e aprovado em 26/10/2021.
} 
RESUMO: Este artigo questiona a existência, no Brasil, de procedimento para a realização do reconhecimento criminal de pessoa a partir de vídeo de vigilância. A hipótese é de que a regulação existente não compreende as particularidades do vídeo, fazendo-se necessários aportes epistêmicos para um procedimento específico, confiável e válido. A metodologia compreende análise da legislação, revisão de literatura e pesquisa empírica qualitativa em acórdãos criminais a fim de examinar as particularidades da prática criminal. Os resultados demostram a inexistência de uniformidade procedimental e a configuração de uma valoração judicial que trata a imagem como retrato fiel da realidade.

PALAVRAS-CHAVE: Reconhecimento de pessoa; prova em vídeo; procedimento; interpretação visual.

ABSTRACT: The issue analyzed in this article concerns the existence of a procedure that determines, in Brazil, how execute a criminal recognition of person based on surveillance video. The hypothesis is that the existing regulation does not comprehend the particularities of the video, being necessary to analyze possible epistemic contributions for the regulation of a specific, reliable and valid ritual. The methodology comprises, in addition to the analysis of legislation and literature review, qualitative empirical research on criminal judgments in order to examine the particularities of criminal practice. The results demonstrate the absence of procedural uniformity and the configuration of a judicial valuation that treats the image as a faithful portrait of reality.

KEYWORDS: Eyewitness identification; video evidence; procedure; visual interpretation.

\section{INTRODUÇÃO}

Os sistemas de vigilância públicos e privados proliferaram como forma de controle social, repercutindo no processo judicial, que passa a lidar cada vez mais com a imagem registrada em vídeo como meio de prova. Esse recurso tornou-se recorrente nas questões criminais, desde a fase de inquérito, passando pela oferta da denúncia, pela instrução, até o julgamento final. Logo, o processo penal convive com um meio de prova complexo e 
ambíguo: a prova em vídeo. Isso é relevante na questão no reconhecimento de pessoa, particularmente quando embasado em vídeos de vigilância.

A utilização do vídeo na esfera judicial deve considerar criticamente as características intrínsecas a esse meio de prova. $\mathrm{O}$ vídeo, especialmente o de vigilância, não deve ser compreendido como um dado objetivo, mas um meio construído, reflexo de um ponto de vista específico. ${ }^{2}{ }^{3}$ Busca-se, nesta sede, desmistificar a ideia do vídeo como prova inequívoca e objetiva.

Nesse contexto de ubiquidade imagética e do uso crescente de vídeos de vigilância na investigação criminal, este artigo tem por objetivo geral investigar o uso de vídeos de vigilância para o reconhecimento de pessoa no processo penal brasileiro. Será realizada análise de acórdãos em que se possa verificar: como é realizado o reconhecimento criminal de pessoas a partir do vídeo; se o procedimento adotado é admitido nas cortes criminais; como o vídeo é valorado pelos julgadores.

Os principais questionamentos a serem respondidos são: há, na legislação brasileira, procedimento relativo ao reconhecimento criminal de pessoas a partir de vídeo de vigilância? Qual é o procedimento utilizado na práxis judiciária?

São objetivos específicos do artigo: a) investigar as peculiaridades da imagem e a complexidade dos vídeos de vigilância; b) analisar o procedimento de reconhecimento criminal de pessoas previsto no Código de Processo Penal (CPP) brasileiro; e c) compreender se o procedimento do CPP brasileiro se adapta ao reconhecimento de pessoa por vídeo; d) analisar possíveis aportes epistêmicos para a produção e análise desta prova, considerando a literatura e as pesquisas empíricas já existentes.

\footnotetext{
${ }^{2}$ SILBEY, Jessica. Cross-examining film. University of Maryland Law Journal of Race, Religion, Gender and Class. Baltimore, vol. 8, n. 1, p. 17-46, 2008, especificamente p. 18.

${ }^{3}$ Considerando a escassa literatura dos ordenamentos de civil law sobre a prova em vídeo, adotou-se referencial teórico norte-americano; nos Estados Unidos, a discussão sobre vídeo é explorada, e foi alvo de debate na Suprema Corte no julgamento Scott $x$ Harris. A base teórica proveniente de common law não afasta o intuito de considerar as particularidades do ordenamento brasileiro, sobretudo a característica formalista e escrita do sistema.
} 
Tendo em vista as considerações específicas sobre a prova em vídeo, delineadas ao longo do texto com respaldo nos estudos de Silbey $^{4}$ e Sherwin ${ }^{5}$, a hipótese defendida é a da inaplicabilidade do procedimento de reconhecimento de pessoas previsto no CPP à identificação a partir do vídeo.

Não são alvo deste trabalho as técnicas de inteligência artificial utilizadas para reconhecimento facial a partir de bancos de dados públicos ou privados. O estudo foca no reconhecimento criminal intermediado pela atividade intelectual humana. São hipóteses dependentes da memória e percepção do indivíduo que analisa a imagem e identifica o suspeito.

\section{A COMPLEXIDADE DA IMAGEM CAPTADA PELAS CÂMERAS}

As novas formas de controle e vigilância a partir de meios tecnológicos e da profusão de imagens caracterizam o que Sherwin ${ }^{6}$ denomina barroco digital. Segundo ele, a imagem propicia um senso de presença que não pode ser facilmente explicado; trata-se do sublime visual. Já a proliferação de formas visuais provoca uma aflição da visão, uma sensação de deslocamento e confusão que nomeia como barroco visual ${ }^{7}$. Diante desses fenômenos, a objetividade da imagem deve ser desmistificada.

O primeiro alerta se dá no sentido de que a imagem, seja ela uma fotografia ou um vídeo, é um meio construído, lançando luz sobre determinado ponto e ocultando as demais perspectivas. A imagem é um olhar de determinado cinegrafista ${ }^{8}$. Cada enquadramento e ângulo de filmagem proporciona uma experiência diferente ${ }^{9}$. Experimentos conduzidos por Lassiter e Irvine ${ }^{10}$ revelaram, por exemplo, o impacto do enquadramento da imagem sobre

\footnotetext{
${ }^{4}$ SILBEY, 2008, passim.

${ }^{5}$ SHERWIN, Richard K. Visualizing law in the age of digital baroque: arabesques and entanglements. London and New York: Routledge, 2011, passim.

${ }^{6}$ Ibid., p. 4.

${ }^{7}$ Ibid.

${ }^{8}$ SILBEY, 2008, p. 18.

${ }^{9}$ SILBEY, Jessica Persuasive visions: film and memory. Law, Culture and Humatinities, vol. 10, n. 1, p. $24-$ 42, 2014, especificamente p. 33-34.

${ }^{10}$ LASSITER, G. Daniel; IRVINE, Audrey A. Videotaped confessions: the impact of camera point of view on judgments of coercion. Journal of Applied Social Psychology, vol. 16, n. 3, p. 268-276, 1986, especialmente p. 272.
} 
a percepção da existência de coerção em confissões gravadas em vídeo. ${ }^{11}$ Há também estudos que verificam os vieses cognitivos das câmeras utilizadas por agentes policiais em capacetes ou uniformes. ${ }^{12}$.

Em segundo lugar, ressalta-se a natureza fluida, emocional, subjetiva e não linear da imagem $^{13}$. A forma como se interpretam imagens difere do modo como textos são interpretados. O visual é encarado de uma maneira gestáltica, interpretando-se tudo de uma vez. E o mais perigoso: quando uma imagem é fragmentária, o intérprete a completa ${ }^{14}$. A sensação é a de sublime visual a que Sherwin ${ }^{15}$ se refere: compreende-se o que se vê como se as imagens fossem janelas transparentes para a realidade. ${ }^{16} \mathrm{O}$ indivíduo acredita naquilo que visualiza, como se não fossem necessários cânones ou sintaxe para a interpretação visual. ${ }^{17} \mathrm{~A}$ interpretação de acordo com o senso comum é denominada por Feigenson ${ }^{18}$ de nä̈ve realism, uma tendência de as pessoas identificarem a imagem como a realidade ordinariamente observável.

Quando o vídeo a ser interpretado é de vigilância, a sensação de objetividade e de revelação da realidade é ainda maior, como se testemunha fosse aquele que o assiste. Silbey denomina como evidence verité alguns vídeos que aparentam um retrato inconsciente e sem mediação da realidade dos fatos. ${ }^{19}$ Segundo a autora, esse tipo de filmagem possui, em sua maioria, qualidade ruim. Geralmente, são imagens fora de foco, distantes do objeto e que possuem som e cores de baixa qualidade. A falta de clareza visual seria, na opinião de Silbey, o modo mais simples de invalidá-las ${ }^{20}$.

\footnotetext{
${ }^{11}$ Os estudos indicam que quando a câmera foca primeiro no suspeito, a confissão é interpretada como resultado de uma pequena fração de coerção; quando foca no suspeito e no detetive, é interpretada como o resultado de uma fração moderada de coerção; e quando a câmera foca primeiramente no detetive, é interpretada como grande a fração de coerção utilizada para obter a confissão (ibid.).

${ }^{12}$ BOIVIN, Rèmi et al. The body-worn camera perspective bias. Journal of Experimental Criminology, 13, p. 125-142, 2017, passim.

${ }^{13}$ PORTER, Elizabeth G. Taking images seriously. Columbia Law Review, vol. 114, p. 1687-1782, 2014, especialmente p. 1753.

${ }^{14}$ Ibid.

15 SHERWIN, 2011, passim.

16 PORTER, op. cit., p. 1754.

${ }^{17}$ Ibid.

${ }^{18}$ FEIGENSON, Neil. Visual common sense. In: WAGNER, Anne; SHERWIN, Richard (Org.). Law Culture and Visual Studies. Dordrecht, Heidelberg, New York / London: Springer, p. 105-124, 2014, p. 106 e passim. ${ }^{19}$ SILBEY, 2008, passim.

${ }^{20}$ SILBEY, 2008, p. 39.
} 
Gates explica porque vídeos de vigilância funcionam bem no contexto midiático e no âmbito da prova judicial, apesar da baixa qualidade. A mesma falta de clareza que deveria atribuir indeterminação às imagens de vigilância atua, paradoxalmente, de forma a atribuirlhes uma dose maior de credibilidade. ${ }^{21}$ Por serem captadas "em tempo real", as imagens possuem uma áurea de "não produção" que traz autenticidade - uma estética de objetividade. Contudo, muitas imagens que circulam na mídia - assim como pode ocorrer com aquelas apresentadas em juízo - não são tão "cruas" quanto aparentam: foram tratadas no sentido de se escolher o melhor momento, assim como de clarear a imagem e de tornar detalhes relevantes mais visíveis. ${ }^{22}$

A partir desse raciocínio, Gates lembra que mesmo quando as câmeras captam um determinado sujeito praticando um crime, sua identificação, persecução e condenação geralmente exigem provas adicionais. Também não se podem ignorar as implicações da circulação midiática de imagens, ainda que fixas (fotografias que expressam determinados frames), extraídas de um vídeo de segurança. ${ }^{23}$ Essas imagens, diz Gates, não carregam apenas um valor probatório, mas também autorizam uma forma simbólica - e passiva - de participação pública na investigação. ${ }^{24} \mathrm{O}$ público é convidado a adotar a perspectiva da própria polícia judiciária pois, a partir das informações captadas em tempo real, acredita conhecer o fato com o olhar próprio dos investigadores.

Nesse contexto, há um universo de subjetivismo desconhecido pelo espectador do vídeo, sempre convicto de ter a verdade ao alcance do olhar.

\section{O RECONHECIMENTO POR VÍDEO DE VIGILÂNCIA E O PROCEDIMENTO PREVISTO NO CPP PARA O RECONHECIMENTO PRESENCIAL}

Como previamente aventado, este trabalho tem como foco a questão da existência de procedimento adequado para as hipóteses em que o reconhecimento de pessoa é realizado a

\footnotetext{
${ }^{21}$ GATES, Kelly. The cultural labor of surveillance: video forensics, computational objectivity, and the production of visual evidence. Social Semiotics, Londres, vol. 23, n. 2, p. 242-260, 2013, especialmente p. 243. ${ }_{22}^{2}$ Ibid.

${ }^{23}$ Ibid., p. 243-244.

${ }^{24}$ Ibid.
} 
partir de vídeo de vigilância. Assim, apresenta-se aqui breve introdução sobre as formalidades previstas nos arts. 226 a 228 do CPP brasileiro para o reconhecimento. Isso é relevante para estabelecer a conexão entre os critérios legais e a natureza da imagem mediatizada.

Badaró $^{25}$ define o reconhecimento como "meio de prova no qual alguém é chamado para descrever uma pessoa ou coisa por ele vista no passado, para verificar e confirmar a sua identidade perante outras pessoas ou coisas semelhantes às descritas.”. O procedimento legal prevê 4 fases: primeiramente, a pessoa a proceder ao reconhecimento descreverá o indivíduo a ser reconhecido; o suspeito será colocado, se possível, ao lado de outros que com ele tiverem semelhança; convida-se o reconhecedor a apontar o sujeito a ser reconhecido; lavrase auto pormenorizado subscrito por autoridade, pelo reconhecedor e por duas testemunhas.

Algumas considerações são necessárias antes de proceder à comparação desse procedimento com o reconhecimento a partir do vídeo de vigilância.

Em primeiro lugar, a previsão dos arts. 226 a 228 do CPP contém limitações insuficientes à proteção da inocência do acusado e à própria finalidade epistemológica da prova. ${ }^{26}$ Há, nesse sentido, estudos inovadores da psicologia cognitiva, com destaque para o relato de Cecconello e Stein sobre experimentos indicativos de menor probabilidade de reconhecimento por indivíduos que tenham descrito previamente o suspeito, em razão do chamado eclipse verbal (overshaddowing effect - efeito decorrente da limitação da linguagem e memória humanas). ${ }^{27}$ Esses autores alertam para a possibilidade de contaminação do testemunho quando formuladas perguntas fechadas (ex.: o suspeito tinha tatuagem?) e chamam a atenção para procedimentos tendentes a resultados pouco

\footnotetext{
${ }^{25}$ BADARÓ, Gustavo Henrique. Processo penal. 8. ed. São Paulo: RT, 2020, p. 568.

26 "Se a redução de erros fosse um objetivo institucional, então de fato seria necessário rever as formalidades constantes do art. 226 do CPP, mas, para robustecê-las. A regra referente ao reconhecimento deveria refletir conhecimentos alcançados por outras ciências.” (MATIDA, Janaína Roland. Standards de prova: a modéstia necessária a juízes e o abandono da prova por convicção. In: CALDAS, Diana Furtado et al. Arquivos da resistência: ensaios e anais do IV seminário nacional do IBADPP. 1 ed. Florianópolis: Tirant to blanch, 2019, p. 93-110, especialmente p. 108).

${ }^{27}$ CECCONELLO, William Weber; STEIN, Lilian Milnitsky. Prevenindo injustiças: como a psicologia do testemunho pode ajudar a compreender e prevenir o falso reconhecimento de suspeitos. Avances en Psicologia Latinoamericana, Bogotá, vol. 38 (1), p. 172-188, 2020, especialmente p. 177-180.
} 
confiáveis. ${ }^{28} \mathrm{O}$ melhor procedimento seria o line-up, alinhando o rosto do suspeito aos de pessoas sabidamente inocentes, similares ao primeiro. A recomendação é que o suspeito seja apresentado em um conjunto de no mínimo 6 e no máximo 12 faces ${ }^{29}{ }_{-30}$

Em segundo lugar, apesar de tais dispositivos traduzirem uma garantia mínima para a credibilidade do reconhecimento, e em que pese a baixa confiabilidade ${ }^{31}$ dos reconhecimentos realizados sem a observação do já insuficiente procedimento descrito pelo art. 226 do CPP, ${ }^{32}$ a previsão legal vinha sendo encarada majoritariamente, como mera recomendação pelos tribunais pátrios ${ }^{33}$. Houve significativo avanço no entendimento do STJ quanto ao ponto, ao concluir pela nulidade de condenação baseada apenas em reconhecimento fotográfico não procedimental, por considerar a regra do art. 226 do CPP garantia mínima ao acusado ${ }^{34}$. A fundamentação é expressa no sentido de que não se trata de mera recomendação do legislador, pois a não observância do procedimento enseja a nulidade da prova. ${ }^{35}$

Apesar da inovação trazida por este acórdão, que afirma ser “[...] de se exigir que as polícias judiciárias (civis e federal) realizem sua função investigativa comprometidas com o

${ }^{28}$ Como o show-up - apresentação de suspeito único, como num teste de verdadeiro ou falso - e o reconhecimento a partir de álbum fotográfico - por serem fichados pela polícia, a testemunha vê todos os rostos como potencialmente suspeitos, além do que o grande número de rostos sobrecarrega os processos cognitivos. ${ }^{29}$ CECCONELLO; STEIN, 2020, p. 177-180.

${ }^{30}$ Existem, até mesmo, trabalhos demonstrar a fragilidade do valor probatório do reconhecimento por testemunho, se comparado a outros meios probatórios, como o exame de DNA. V. WELLS, G.L. et. al. Eyewitness evidence: improving its probative value. Psychological Science in the Public Interest, vol. 7, n. 2, 45-75, 2006.

${ }^{31}$ A falta de credibilidade do reconhecimento feito em inobservância desses passos é destacada por Lopes Jr. Direito processual penal. 14 ed. São Paulo: Saraiva, 2017, p. 487-490).

32 "Se sequer a fila (line up) foi realizada, não há razões para concluir, de maneira otimista, que os oficiais responsáveis pelo procedimento, estiveram dispostos a não sugerir suspeitos para serem identificados [...] A indiferença institucional com a qual as provas de identificação foram produzidas nos casos aqui examinados foi aperfeiçoada pela falta de modéstia dos julgadores, que não hesitaram em valorar como suficientes as provas em razão do caráter recomendatório do artigo 226 do CPP." (MATIDA, 2019, p. 107).

33 "Esta Corte Superior de Justiça firmou o entendimento no sentido de que as disposições insculpidas no artigo 226 do Código de Processo Penal configuram uma recomendação legal, e não uma exigência, cuja inobservância não enseja a nulidade do ato" (Agravo Regimental no Agravo em Recurso Especial 1665453/SP. Relator: Min. Joel Ilan Paciornik. 5 Turma. Brasília, 02 jun. 2020. Disponível em: https://bit.ly/2RqQB5R. Acesso em: 15 maio 2021).

${ }^{34}$ BRASIL, Habeas Corpus 598.886/SC. Voto do Relator Min. Rogerio Schietti Cruz. 6 ${ }^{\mathrm{a}}$ Turma. Brasília, 27 out. 2020. Disponível em: https://bit.ly/2G6B496. Acesso em: 28 maio 2021.

35 Sobre a decisão o tema, conferir os comentários de Cecconello, Stein e Ávila (Novos rumos para o reconhecimento de pessoas no Brasil? Perspectivas da psicologia do testemunho frente à decisão do HC 598.886-SC. Revista brasileira de ciências criminais, vol. 177, mar. 2021, p. 359-368, 2021). 
absoluto respeito às formalidades desse meio de prova" ${ }^{36}$, são muitas as violações constatadas, algumas delas indicadas por estudo empírico publicado pelo Ministério da Justiça em colaboração com o IPEA. ${ }^{37}$ Os problemas começam antes da atuação investigativa da polícia civil: os policiais militares necessitam buscar rapidamente quem cometeu o delito - muitos reconhecimentos, assim, são realizados seguindo a técnica do show-up, ou por álbum de fotografias; raramente existe a estrutura necessária (especialmente o vidro técnico); há dificuldades na apresentação em line up de pessoas com características físicas semelhantes ao suspeito, sendo que os policiais já o conhecem previamente e o colocam junto a outros presos para a identificação. ${ }^{38}$

As disposições contidas nos arts. 226 a 228, associadas aos estudos citados, corroboram o fato de que o direito processual penal busca regular o reconhecimento de pessoa de modo a evitar minimamente o sugestionamento da vítima ou da testemunha pelo órgão judicial ou polícia judiciária. Assim, ainda que questionáveis a eficácia e atualidade das técnicas utilizadas no dispositivo ${ }^{39}$, por certo constituem garantia mínima à consecução da finalidade epistêmica da prova por reconhecimento de pessoa. Em decorrência, são ferramentas imprescindíveis à preservação do status de inocência do acusado, pois atuam diretamente na prevenção de falsas imputações.

A simples leitura do conteúdo dos dispositivos legais e a análise do procedimento previsto já indicam a dificuldade de adequação ao reconhecimento por vídeo de vigilância. Este trabalho analisará o reconhecimento do suspeito a partir de imagens do fato criminoso ou de eventos a ele relacionados, e, não, da formação de line up a partir de vídeos gravados

\footnotetext{
${ }^{36}$ BRASIL, Habeas Corpus 598.886/SC, 2020.

37 "Identificamos, portanto, em nosso levantamento de campo a dificuldade dos atores jurídicos em observar até mesmo as regras mínimas previstas no CPP” (MINISTÉRIO DA JUSTIÇA; IPEA. Avanços científicos em psicologia do testemunho aplicados ao reconhecimento pessoal e aos depoimentos forenses. Brasília: Ministério da Justiça, Secretaria de Assuntos Legislativos (SAL); Ipea, 2015., p. 69).

${ }^{38}$ MINISTÉRIO DA JUSTIÇA; IPEA, 2015.

${ }^{39} \mathrm{O}$ Innocence Project constatou que identificações equivocadas realizadas por testemunhas contribuíram para aproximadamente $71 \%$ de mais de 360 condenações errôneas nos Estados Unidos. Exigências procedimentais foram sugeridas: formação de fila duplo-cego; instrução da testemunha quanto à não obrigatoriedade de selecionar um suspeito; formação da line up sem chamar atenção para o suspeito; declaração da testemunha sobre o nível de confiança no reconhecimento; documentação eletrônica do procedimento (INNOCENCE PROJECT. Eyewitness identification reform. Disponível em: https://www.innocenceproject.org/eyewitnessidentification-reform/. Acesso em 28 maio 2021).
} 
em ambiente controlado de acordo com regras pré-estabelecidas, como previsto no sistema inglês. ${ }^{40}$

Quanto ao vídeo de vigilância, a comparação com o disposto no CPP traz à tona uma série de questionamentos. Como poderá o reconhecedor descrever o suspeito, se provavelmente a primeira vez que o verá será no vídeo a ser exibido? Como o suspeito poderá ser posicionado entre pessoas semelhantes a ele, se não há indivíduo físico a ser identificado como possível criminoso? Esse procedimento pode ser considerado irrepetível?

No caso do reconhecimento presencial, não só é determinada por lei a descrição prévia do sujeito a ser reconhecido, como também é aconselhável que a testemunha não tenha tido contato com ele entre a data do crime e o ato de reconhecimento.

Ainda a propósito dessa modalidade de reconhecimento, há estudos que apontam para a irrepetibilidade do procedimento, baseando-se no comprometimento psíquico gerado pelo primeiro ato de reconhecimento. ${ }^{41}$ Não se trata de uma impossibilidade prática de se repetir o procedimento, mas de medida de prevenção de erros no resultado da prova, verdadeiro limite epistemológico ao reconhecimento de pessoa.

De forma radical, Jauchen ${ }^{42}$ sustenta que o ato de reconhecimento é definitivo e irreproduzível, porque o juízo de identidade ou diferença que o reconhecedor expressa é uma experiência única: uma vez efetuada e obtido o resultado negativo ou positivo, torna-se ineficaz uma nova realização. Apesar de tais informações, o STJ possui posicionamento no sentido de: "não haver nulidade quando o reconhecimento fotográfico realizado na fase investigatória é ratificado em juízo." ${ }^{43}$. Mesmo no acórdão mais recente, a $6^{\text {a Turma, que }}$ afirmou ser necessário seguir as formalidades do art. 226, CPP, o voto do Relator considera

\footnotetext{
${ }^{40}$ FITZGERALD, Ryan J.; PRICE, Heather L.; VALENTINE, Tim. Eyewitness identification: live, photo, and video lineups. Psychologic, Public Policy, and Law, vol. 24, n. 3, p. 307-325, 2018, especialmente p. 314; HORRY, Ruth et al. Predictors of eyewitness identification decisions from video lineups in England: a field study. Law and Human Behavior, vol. 36, n. 4, p. 257-265, 2012, especialmente p. 258.

${ }^{41}$ Cf. LOPES JR., 2017, p. 494-495.

${ }^{42}$ JAUCHEN, Eduardo M. Tratado de la prueba en material penal. Santa Fe: Rubinzal-Culzoni, 2009, p.464.

${ }^{43}$ BRASIL, STJ, Agravo Regimental no Agravo Regimental no Agravo em Recurso Especial 1585502/SP. Relator: Min. Joel Ilan Paciornik. 5a Turma. Brasília, 06 fev. 2020. Disponível em: https://bit.ly/2ZEodkZ. Acesso em: 15 maio 2021.
} 
possível a repetibilidade ${ }^{44}$, apesar de citar estudos que entendem pela impossibilidade da repetição e examiná-los.

O reconhecimento por vídeo de vigilância possui peculiaridades que o fazem distinto do procedimento previsto para o reconhecimento presencial de pessoa, sendo inaplicáveis as mínimas garantias epistemológicas estabelecidas nos arts. 226 a 228 do CPP.

Veja-se que a técnica prevista no CPP sequer pode servir de diretriz para o reconhecimento por vídeo de vigilância, como sustentam alguns, por exemplo, para as situações de reconhecimento por fotografia. ${ }^{45}$ Nesse último caso, em que pesem as ressalvas doutrinárias sobre o tema, ${ }^{46}$ ainda é possível proceder a um arremedo de adaptação procedimental, impondo à testemunha uma descrição prévia da pessoa a ser reconhecida e contrapondo fotografias de sujeitos semelhantes. ${ }^{47}$ No vídeo de vigilância, tal adaptação que, por si, já é insuficiente - não é viável. Acrescem, ainda, as especificidades da prova audiovisual previamente mencionadas.

Tudo isso reforça a tese da inadequação das disposições procedimentais destinadas ao reconhecimento de pessoa às hipóteses em que o agente é reconhecido a partir de vídeo de vigilância.

\footnotetext{
44 “O reconhecimento do suspeito por simples exibição de fotografia(s) ao reconhecedor, a par de dever seguir o mesmo procedimento do reconhecimento pessoal, há de ser visto como etapa antecedente a eventual reconhecimento pessoal e, portanto, não pode servir como prova em ação penal, ainda que confirmado em juízo" (BRASIL, STJ, HC 598.886/SC, 2020).

${ }^{45}$ O STJ se posiciona pela validade do reconhecimento fotográfico: “A jurisprudência deste Tribunal Superior admite a possibilidade de reconhecimento do acusado por meio fotográfico, ainda que não observadas a totalidade das formalidades contidas no art. 226 do Código de Processo Penal." (BRASIL, STJ, AgRg no HC 525027/SP, 2019). Em dissonância, recentemente, a $6^{a}$ Turma considerou inválido reconhecimento fotográfico em inobservância das formalidades do art. 226 do CPP (BRASIL, STJ, RHC 133.408/SC, Relator: Min. Sebastião Reis Júnior, $6^{\mathrm{a}}$ Turma. Brasília, 15 dez. 2020. Disponível em: https://scon.stj.jus.br/SCON/GetInteiroTeorDoAcordao?num_registro=202002175790\&dt_publicacao=18/12 12020. Acesso em: 14 jul. 2021.).

${ }^{46}$ Dean diz que o reconhecimento fotográfico não é assimilável ao paradigma do reconhecimento de pessoa pois, embora com função genericamente coincidente, há uma diferença marcante de objetos, sendo certo que a lei determinou como elemento essencial a presença da pessoa a ser reconhecida, em sua forma física (DEAN, Giovanni. In tema di 'libertà' e 'tassatività' delle forme nell'acquizione probatoria a proposito delle 'ricognizione fotografica'. Rivista italiana di diritto e procedura penale. Milano: Giuffrè, 1989, p. 826-842, especialmente p. 828-829).

47 Há sobrecarga dos processos cognitivos e a capacidade de reconhecer corretamente fica dificultada. Ademais, todos os rostos apresentados para a testemunha são potenciais suspeitos. Badaró (2020, p. 572) acrescenta que "[...] a imagem não proporciona os elementos do exame físico, como o gesto, o andar, a mudança da expressão." Fitzgerald et. al. (2018, p. 321), por sua vez, registram o ganho prático das filas de reconhecimento não presenciais (fotos e vídeos), por não haver evidências empíricas da superioridade do reconhecimento presencial.
} 


\section{NOVAS QUESTÕES E POSSÍVEIS APORTES EPISTEMOLÓGICOS}

Essas breves considerações sobre o reconhecimento de pessoa no CPP levam a questionamentos específicos quanto aos vídeos de vigilância. Indaga-se: o reconhecimento por vídeo pressupõe ou pode pressupor o conhecimento prévio, pelo reconhecedor, do sujeito a ser reconhecido? Há fatores que possam auxiliar no controle de erros nessa modalidade de reconhecimento $?^{48}$ A preservação da fonte do vídeo, bem como o conhecimento de todas as fases de armazenamento, seria imprescindível à admissibilidade deste meio de prova em juízo? A dúvida sobre a autenticidade ou idoneidade das imagens poderia ensejar seu desentranhamento dos autos, ou apenas produziria impactos sobre a valoração da prova? ${ }^{49}$ Eventual conhecimento da existência de imagens captadas sob um ângulo diverso, que tenham sido descartadas pela acusação, contaminariam a legalidade do vídeo de vigilância utilizado para fins de comprovar a autoria?

A práxis criminal revela uma variedade de formas de identificação a partir do vídeo de vigilância. Vislumbram-se, até o momento, as seguintes possibilidades: apresentação do vídeo de vigilância ao reconhecedor para que indique, a partir de atividade cognitiva e dependente de memória, quem seria a pessoa gravada; a submissão de pessoa que não presenciou os fatos, mas assistiu ao vídeo de vigilância, à fila de reconhecimento presencial para indicação de reconhecido; apresentação de vídeo de vigilância ao júri ou ao juiz a fim

\footnotetext{
${ }^{48}$ Segundo Bruce et. al. (Verification of face identities from images captured on video. Journal of Experimental Psychology, vol. 5, n. 4, p. 339-360, 1999, especialmente p. 339-340) a identificação a partir de vídeo de circuito de vigilância depende das circunstâncias. São situações distintas: aquela em que o agente captado em vídeo é preso em flagrante na cena do crime, tendo sido acompanhado por câmeras de segurança desde o momento do fato até sua captura, daquela em que o indivíduo é gravado em imagens, mas consegue escapar do incidente. Nesta última será necessário verificar a similitude da pessoa capturada com o acusado denunciado; a qualidade ruim das imagens pode dificultar (ibid.).

49 Os últimos questionamentos referem-se à preservação da cadeia de custódia da prova, positivada no CPP para a prova pericial pela Lei 13.964 de 2019. Prado (A cadeia de custódia da prova no processo penal. São Paulo: Marcial Pons, 2019, p. 95) indica como garantidores da fiabilidade da prova: a mesmidade (o que se encontrou na cena do crime é o mesmo que se utiliza para julgar) e a desconfiança (duvidar da validade da prova, questionando se houve alteração). A documentação da cadeia de custódia é relevante quando se trata de provas digitais, dada sua característica fragilidade e possibilidade de alteração ( $C f$. VIEIRA, Thiago. Aspectos técnicos e jurídicos da prova digital no processo penal. Disponível em: https://medium.com/@tocvieira/aspectos-t\%C3\%A9cnicos-e-jur\%C3\%ADdicos-da-prova-digital-no-
} processo-penal-aa22ef05fb30\#_ftn15. Acesso em: 27 maio 2021. Publicado em 22 out. 2019). 
de que, a partir de atividade de percepção, os julgadores possam verificar se o réu é a pessoa gravada; sujeição do vídeo a exame pericial para que especialista confirme se suspeito é a pessoa gravada a partir de comparação de imagens. ${ }^{50}$

Diante da ausência de procedimento legal, afigura-se útil a análise de estudos interdisciplinares que conduzam a reflexões epistêmicas sobre possíveis critérios de redução da margem de erros no reconhecimento a partir de vídeos de vigilância.

Estudos de psicologia cognitiva indicam a capacidade humana de reconhecer faces familiares a partir de vídeos com baixa qualidade; em contraste, o reconhecimento de faces não familiares seria altamente suscetível a erros. ${ }^{51}$ Chega-se a concluir pela incapacidade de reconhecimento por indivíduos não familiares ao alvo. ${ }^{52}$ Por outro lado, a capacidade de reconhecer faces familiares pode levar o indivíduo à crença na aptidão para reconhecer faces não familiares com a mesma acuidade, supervalorizando o reconhecimento criminal de pessoas. $^{53}$

Como os experimentos foram realizados em ambientes específicos, geralmente controlados, provavelmente não compreendem todas as peculiaridades da investigação criminal. Nesse sentido, Burton et. $a l^{54}$ enfatizam que os participantes já imaginavam que iriam reconhecer indivíduos que frequentavam determinado ambiente. Logo, a ajuda fornecida pelo contexto e pela expectativa preestabelecida nos participantes não pode ser desprezada. Deve-se analisar esses experimentos no âmbito restrito dos respectivos objetos. ${ }^{55}$ Nessa perspectiva, o que parece correto extrair, para efeitos de critério para o

\footnotetext{
${ }^{50}$ Ademais, poderia o vídeo de vigilância ser utilizado em sistema de reconhecimento facial automático a partir de softwares de inteligência artificial. Entretanto, como dito na introdução, este trabalho tratará apenas dos reconhecimentos dependentes de atividade humana intermediada.

${ }^{51}$ Explicam Cecconello e Stein (2020, p. 175): "Ainda que sejamos capazes de codificar, armazenar, e reconhecer um grande número de faces nem todos os rostos os quais fomos expostos são codificados corretamente. [...] Isto ocorre por que a memória humana é 'especializada' em aprender e a representação mental do rosto de uma pessoa torna-se mais precisa à medida que somos expostos a este, ou seja, à medida que aprendemos os traços daquela face (Bruce \& Young, 2012; Memon, \& Bruce, 1985).”

52 BURTON, A. Mike et al. Face recognition in poor-quality video: evidence from security surveillance. Psychological Science, vol. 10, n. 3, p. 243-248, maio 1999, especialmente p. 245.

${ }^{53}$ JENKINS, R.; BURTON, A. M. Limitations in facial identification: the evidence. Justice of the Peace, vol. 172 , p. 4-6, jan. 2008, especialmente p. 4.

${ }_{55}^{54}$ BURTON et al., 1999, p. 248.

${ }^{55}$ Num estudo experimental de referência, foram considerados familiares aos alvos - professores do Departamento de Psicologia da Universidade de Glasgow - aqueles alunos que assistem aulas no próprio
} 
reconhecimento criminal, é a solidez dos resultados sobre o alto índice de falibilidade do reconhecimento de pessoas não familiarizadas com o reconhecedor. Eventuais vieses cognitivos relevantes, como viés de confirmação (proveniente do chamado "efeito compromisso") não foram objeto da pesquisa. ${ }^{56}$

No âmbito criminal, não há como afirmar, por exemplo, que o reconhecedor já familiarizado com o suspeito, e que tenha conhecimento da suspeita e de outras circunstâncias do fato, não esteja psicologicamente propenso a identificá-lo ou a descartálo. Por isso, afirmar que um indivíduo familiarizado com o alvo está mais propenso a reconhecê-lo não conduz à conclusão de que tais modalidades de reconhecimento sejam sempre eficazes. No âmbito processual penal, a utilização acrítica destes resultados poderia conduzir à violação do standard probatório mais elevado exigido para a condenação.

Um aspecto que parece útil para a valoração do reconhecimento a partir das câmeras de vigilância refere-se à dificuldade de reconhecimento de corpos em movimento ${ }^{57}$. O rosto é o aspecto mais relevante para o sucesso do reconhecimento, em contraposição à compleição física e à movimentação. ${ }^{58}$ Em geral, as câmeras de segurança captam o suspeito em movimento, o que torna esta informação particularmente útil.

A propósito da noção de familiaridade, os estudos realizados apenas consideram "familiarizadas" com o alvo aquelas pessoas que tenham com ele convívio cotidiano e próximo, por um longo período de tempo. Alguns estudos destacam que a relação entre policiais e sujeitos já detidos precedentemente não é suficiente para enquadrar-se no conceito. ${ }^{59}$ Também não adquirem familiaridade os que repetidamente assistem ao vídeo de vigilância. ${ }^{60}$ Ao que parece, a exibição repetida do vídeo, ao contrário de gerar uma expertise

departamento, e não familiares aqueles que assistem aulas em outros departamentos, ou policiais com experiência em reconhecimento criminal (BURTON et al., 1999, p. 243-248).

${ }^{56}$ CECCONELLO, William Weber; AVILA, Gustavo Noronha; STEIN, Lilian Milnitsky. A (ir)repetibilidade da prova penal dependente da memória: uma discussão com base na psicologia do testemunho. Revista Brasileira de Políticas Públicas, [s. 1.], vol. 8, n. 2, p. 1057-1073, 2018, passim.

${ }^{57}$ Mesmo quando os indivíduos sejam pessoalmente familiarizados com os suspeitos, conforme: BURTON et al., 1999 , p. 248.

${ }^{58}$ Ibid., 246-247.

${ }^{59}$ DAVIS, Josh P.; VALENTINE, Tim. CCTV on trial: matching video images with the defendant in the dock. Applied Cognitive Psychology, vol. 23, p. 482-505, maio 2009.

60 Ibid. 
ou uma familiaridade, conduz a um viés. De acordo com Burton et al $l^{61}$, os policiais com experiência em identificação criminal apresentaram performances tão ruins quanto dos sujeitos não familiares aos alvos.

Outro ponto a ser considerado é o cross racial effect, own-race bias ou otherrace effect: a dificuldade ou incapacidade de perceber as diferenças de traços entre sujeitos de etnia diversa a do reconhecedor. ${ }^{62}$ Segundo Cecconello e Stein "atributos característicos daquela etnia podem ser percebidos como distintivos (e.g., nariz largo e lábios espessos em negros; olhos puxados em asiáticos), resultando em uma maior a probabilidade de um falso reconhecimento." ${ }^{63}$ Jenkins e Burton ${ }^{64}$ narram que um trabalho entre universidades no Egito e na Escócia detectou o mesmo fenômeno ao correlacionar fotos: os egípcios apresentaram mais erros correlacionando faces escocesas e vice-versa.

Davis e Valentine, por sua vez, examinaram a capacidade de comparar o réu presente no tribunal com um indivíduo gravado em vídeo de vigilância, verificando que o reconhecimento da pessoa no vídeo é altamente suscetível a erros. ${ }^{65}$ No mesmo sentido apontaram os resultados de Bruce e outros ${ }^{66}$. Nestes, verificou-se queda de performance na identificação comparando imagens de ângulos distintos. ${ }^{67}$

Muitos dos estudos citados levam em conta a qualidade dos vídeos de vigilância: uns usaram vídeos gerados por equipamentos de vigilância ${ }^{68}$, outros tentaram se aproximar da realidade de câmera de segurança, ou focaram em vídeos de média ou alta qualidade. Bruce e outros ${ }^{69}$ afirmam que normalmente os vídeos de vigilância possuem baixa qualidade, com as câmeras posicionadas para abranger uma área ampla, sendo o ângulo e a resolução da imagem ruins. Além disso, pode ser que sejam gravados apenas frames, ou, ainda, que o contraste seja ruim ou a imagem possua longas sombras. ${ }^{70}$

\footnotetext{
${ }^{61}$ BURTON et al, 1999 , p. 249.

${ }^{62}$ LOPES, Mariângela Tomé. O reconhecimento como meio de prova: necessidade de reformulação do direito brasileiro. Tese de doutorado. Orientador: Antonio Scarance Fernandes. USP: São Paulo, 2011, p. 109.

${ }^{63}$ CECCONELLO; STEIN, 2020, p. 175.

64 JENKINS; BURTON, 2008, p. 4.

${ }^{65}$ DAVIS; VALENTINE, op. cit., passim e p. 501.

${ }^{66}$ BURTON et al., 1999, passim.

${ }^{67}$ Ibid.

${ }^{68}$ Ibid., passim.

${ }^{69}$ BRUCE, 1999.

${ }^{70}$ BRUCE, 1999, p. 340.
} 
Tsifouti e outros ${ }^{71}$ analisam o nível aceitável de bits em imagens gravadas por vídeos de vigilância de ônibus londrinos, disponibilizando suficiente informação facial remanescente na imagem comprimida a permitir que um especialista identifique a pessoa. Os resultados dependem da iluminação: cenas muito escuras ou muito claras são mais difíceis de comprimir, requerendo maiores níveis de bits para manter a utilidade da informação. $\mathrm{O}$ estudo indica que os sistemas de vigilância deveriam estar configurados para comprimir imagens com níveis de bits em 1500kbps durante o dia, quando há variação de iluminação, e em 700kbps para a noite, quando há iluminação artificial ou no caso de claridade média ou mixed lightness scenes.

Edmond e outros ${ }^{72}$ enumeram critérios para o controle da qualidade da imagem, entre os quais destacam-se: resolução suficiente para apresentar características individuais; certificação da integridade da imagem; análise de problemas de distorção; uso de luz de qualidade para visualização de marcas; uso de lentes sem distorção; verificação do ângulo de filmagem, a fim de evitar distorções de perspectiva. ${ }^{73}$

Em muitos casos, a dúvida sobre a autenticidade ou qualidade suficiente da imagem poderá ensejar prova pericial. Esses aspectos técnicos são relevantes na discussão sobre a admissibilidade e eficácia probatória do reconhecimento a partir de vídeos que não tenham sido periciados.

Há questionamentos quanto à qualificação do expert e quanto à adequação dos métodos periciais para comparação de imagens para identificação com base em vídeo de vigilância.

Edmond e San Roque destacam a visão acrítica com que a prova advinda dos vídeos de vigilância é admitida no processo penal, pois interpretada por especialistas forenses de qualificação duvidosa, normalmente limitada a uma área de conhecimento (especialistas em arte, fotografia, anatomia, ou mesmo em face and body mapping), não necessariamente dotados de habilidade para analisar produtivamente o tipo de imagem de baixa qualidade em

\footnotetext{
71 TSIFOUTI, Anastasia et al. Acceptable bit-rates for human face identification from CCTV imagery. SPIE Proceedings, vol. 8653, p. 1-15, fev. 2013.

72 EDMOND, Gary et. al. Law's looking glass: expert identification evidence derived from photographic and video images. Current Issues in Criminal Justice, vol. 20, n. 3, p. 337-377, mar. 2009, p. 352-353.

${ }^{73}$ Quanto ao ângulo de filmagem, explicam que haverá distorções significativas de forma e tamanho se a câmera não estiver de frente para o indivíduo a ser reconhecido (ibid.).
} 
duas dimensões. Assim, mesmo quando se acredita estar diante de "experts", há uma banalização de conhecimentos mundanos e intuitivos sob a roupagem de uma pretensa especialização, ignorando-se a complexidade associada à interpretação da imagem. Os autores constatam ser recorrente a utilização de depoimentos de policiais já familiarizados com os suspeitos, por terem assistido ao vídeo diversas vezes. ${ }^{74}{ }^{75}$

O panorama se agrava quando o reconhecimento é feito no contexto da exposição do caso, ao lado de outros elementos incriminadores - não necessariamente associados à prova da autoria -, gerando vieses que contaminam a valoração da prova. ${ }^{76}$ Embora a crítica seja direcionada ao sistema do júri, o analfabetismo digital ${ }^{77}$ não está limitado aos jurados, mas estende-se aos profissionais do direito em geral.

Diante de tudo isso, o que se pretende é apenas suscitar alguns parâmetros para a produção de uma prova confiável. Não se trata de buscar um “'ótimo epistêmico', transformando o processo no melhor modelo de descoberta da verdade, como se ela fosse um fim em si mesmo para o julgador." ${ }^{78}$ É preciso assegurar a finalidade epistêmica da prova sem descurar de eventuais limitações contraepistemológicas inerentes ao processo, sobretudo aquelas que asseguram a presunção da inocência. Como não há, até o momento, procedimento legal adequado às peculiaridades do reconhecimento a partir de vídeo de vigilância, deve-se atentar para os riscos que recaem sobre o direito de defesa no momento da produção e valoração da prova.

Por fim, o reconhecimento por vídeo de segurança deve, no mínimo, submeter-se ao contraditório diferido, com a exibição do vídeo em audiência, a possibilidade de provas orais e periciais sobre o conteúdo da mídia e, inclusive, sobre a própria credibilidade e autenticidade do vídeo. ${ }^{79}$

${ }^{74}$ EDMOND, Gary; SAN ROQUE, Mehera. Justicia's gaze: surveillance, evidence and the criminal trial. Surveillance and Society, vol. 11 (3), p. 252-273, 2013.

${ }^{75}$ Sobre a pouca credibilidade desses depoimentos, já se aludiu aos estudos de psicologia cognitiva realizados por BURTON, et al., 1999, p. 243. Veja-se, ainda, DAVIS; VALENTINE, 2009, p. 501.

${ }^{76}$ EDMOND; SAN ROQUE, op. cit., p. 260.

77 SHERWIN, 2011, p. 3; 37.

${ }^{78}$ BADARÓ, Gustavo Henrique. Epistemologia judiciária e prova penal. São Paulo: Thomson Reuters Brasil, 2019 , p. 134.

${ }^{79}$ Nesse último caso, trata-se de prova sobre prova: aquelas provas que não versam diretamente os fatos do caso, mas referem-se à autenticidade e ao grau de credibilidade de outras provas (FERRER BELTRÁN, Jordi. La valoración racional de la prueba. Madrid, Barcelona, Buenos Aires: Marcial Pons, 2007, p. 89). 
Este contraditório sobre o ato de reconhecimento, realizado em juízo não corresponde à repetição da prova. É, antes, o falseamento da indicação do suspeito. Parece razoável que o debate envolva, ao menos: a análise direta do vídeo pelos julgadores; a exibição do vídeo em audiência ou sessão, com possibilidade de argumentação sobre seu conteúdo e, também de inquirição oral a partir dele. ${ }^{80}$ A partir dessas provas, será possível ao magistrado concluir pela viabilidade ou não de um reconhecimento preciso.

Os parâmetros ideais para a produção dessa prova ainda serão alvo de muitas reflexões e estudos, mas os critérios mencionados podem servir de ponto de partida o atendimento da finalidade epistêmica da prova.

\section{BREVE ESTUDO DA REALIDADE BRASILEIRA}

\subsection{Metodologia e coleta dos dados}

Para examinar realidade do reconhecimento de pessoas a partir de vídeo de vigilância no processo penal brasileiro será feita a análise qualitativa de 4 acórdãos provenientes do banco de decisões da pesquisa sobre o uso do vídeo nas cortes brasileiras construído pelos autores do presente trabalho. ${ }^{81}$

Dentre tais acórdãos realizou-se busca por conteúdo a partir dos seguintes termos: câmeras de segurança; câmeras; segurança, a fim de analisar julgamentos em que foram realizados reconhecimentos criminais a partir de vídeo de vigilância. $\mathrm{O}$ critério de seleção dos acórdãos aqui analisados foi a heterogeneidade das realidades demonstradas, a fim de ilustrar a falta de uniformidade no procedimento e no tratamento da imagem.

${ }^{80}$ SILBEY, 2008, p. 19; 41-45; RICCIO, Vicente et al. Imagem e retórica na prova em vídeo. RIL, Brasília, a. 55 , n. 220 , p. $85-103$, out./dez. 2018.

${ }^{81} \mathrm{O}$ referido banco de decisões foi formado a partir de pesquisas pelos termos prova e vídeo nos sites dos Tribunais de Justiça de São Paulo, Minas Gerais e Rio de Janeiro, selecionando acórdãos cíveis e criminais que apresentassem os dois termos concomitantemente. Propôs-se verificar se os magistrados dos três estados mais populosos do Brasil assistiam ou não ao vídeo quando este presente no conjunto probatório como prova. No âmbito criminal, há 491 acórdãos filtrados julgados entre os anos de 2014 a 2019 em que foi empregada pelo menos uma prova em vídeo. 


\subsection{Apresentação dos dados}

\subsubsection{Primeiro acórdão - reconhecimento em vídeo sem captação facial por policiais}

O primeiro acórdão confirma sentença condenatória relativa a furto realizado em residência e captado por câmera de segurança de estabelecimento vizinho ao local do fato. Em sede de apelação, confirmou-se a sentença condenatória por se considerarem "bastantes ao decreto condenatório" os depoimentos da vítima e de testemunhas.

O vídeo foi alvo do depoimento de testemunhas - uma delas um policial - e da vítima, que afirmaram reconhecer o réu por terem assistido ao vídeo de segurança. Não se há menção à exibição do vídeo em juízo, mas apenas à existência de fotos - provavelmente frames do vídeo - nos autos. Não há referência a qualquer procedimento para o reconhecimento ou a questionamentos sobre o tratamento das imagens.

Nos termos do relatório do acórdão "o denunciado, conhecido nos meios policiais por delitos da mesma natureza, foi identificado pelas imagens da câmera de segurança do estabelecimento vizinho ao local dos fatos, bem como reconhecido por uma testemunha.". 82

Da fundamentação do voto do relator é possível extrair que os depoimentos da vítima e do policial - que apontou a identidade do suspeito - basearam-se exclusivamente no vídeo de segurança. Há também uma testemunha circunstancial, que teria avistado o réu nas imediações do local do fato. ${ }^{83}$

\footnotetext{
${ }^{82}$ SÃO PAULO. Tribunal de Justiça. Apelação Criminal 0002525-58.2014.8.26.0294. Relator: Des. Otávio de Almeida Toledo. 16 $6^{\mathrm{a}}$ Câmara Criminal. São Paulo, 05 jul. 2016. Disponível em: http://esaj.tjsp.jus.br/cjsg/getArquivo.do?cdAcordao=9583836\&cdForo=0. Acesso em: 15 mar. 2021.

83 "No momento do crime, a testemunha [...], que trabalha no estabelecimento comercial vizinho à vítima, viu o réu rondando a casa, identificando-o como sendo o réu. Disse que ele sentava e levantava defronte ao estabelecimento comercial e em dado momento o perdeu de vista. Posteriormente viu pela câmera de segurança que ele pulou o muro da residência, não sabendo precisar se ele nela ingressou, mas o viu momentos depois passar novamente deixando o local. A vítima [...] disse que ao chegar em casa com seu filho e esposa, seu filho notou o sumiço do dinheiro. A funcionária do estabelecimento contou ter visto o réu rondando a casa. Ao ver o vídeo da camera de segurança, pode notar que o réu some das imagens defronte à sua casa, cujo portão e porta da frente ficavam destrancados". (ibid.)
} 
Consta do acórdão que o policial “contou que o réu já é conhecido dos meios policiais por outros furtos", e ainda, que "assistiu ao vídeo e não teve dúvidas de que se trata do réu. Nas imagens dá para ver ele ingressando e saindo da residência" ${ }^{84}$ (ibid.).

$\mathrm{O}$ réu negou a autoria.

No voto condutor do acórdão considerou-se que: "Em que pese a negativa do acusado, bem como ainda não haver testemunha presencial do réu ingressando na residência, a dinâmica dos fatos contada pela vítima e testemunhas deixam clara a autoria do crime." ${ }^{, 5}$

À luz do que se analisou nos tópicos precedentes, diversos questionamentos podem ser suscitados. O primeiro refere-se à circunstância de se reconhecer no vídeo alguém previamente visto pela testemunha ou vítima. É certo que os estudos realizados apontam a familiaridade como um aspecto positivo para o reconhecimento, mas este não é o caso. Tratase de alguém já visto previamente, não necessariamente um rosto familiar.

Pode-se argumentar que, por vezes, isso será inevitável no reconhecimento a partir do vídeo. Mas há que se refletir sobre os mecanismos psicológicos que levaram o policial a mentalmente "pré-selecionar" pessoas parecidas com o sujeito do vídeo. Diversamente do reconhecimento facial por meio de inteligência artificial, e do reconhecimento de pessoa pelo rito do CPP, o sujeito que reconhece não tem um "banco de dados" ou uma "fila" prédeterminada e verificável. A memória e os mecanismos de seleção funcionam de forma distinta, e o controle sobre eles deve levar isso em conta.

No caso, o policial identificou o agente do vídeo como alguém “já conhecido dos meios policiais por outros furtos", sem que sequer pudesse ver-lhe o rosto. Este fato justificaria o argumento de o depoimento estar viciado por uma ideia preconcebida sobre a identidade do agente?

\footnotetext{
${ }^{84}$ Ibid.

${ }^{85}$ Ibid. Tal "dinâmica dos fatos" é descrita no acórdão: "O réu ronda o local por algum tempo, depois, defronte à residência do réu, desaparece das imagens, acostadas às fls. 09/13. O fato das fotografias captarem o réu apenas de costas não abala a prova de autoria. Igualmente não fragiliza a prova de autoria alguma dúvida se de fato o vídeo da câmera de segurança captam as imagens do rosto do réu. Ainda que assim não seja, de ser ver que a testemunha [...] reconheceu em audiência o réu como a pessoa que aparece no vídeo, pois já o conhecia de vista anteriormente. Afirmou em juízo não apenas ser ele quem aparece no vídeo, bem como que o viu pulando o muro da casa da vítima. O policial [...] igualmente dá conta de que o vídeo está a demonstrar o réu ingressando e saindo da casa da vítima, fato igualmente confirmado pela vítima [...]”. (ibid.)
} 
Sob a ótica dos numerosos estudos que atestam a importância da face no reconhecimento e a dificuldade de se identificar corpos em movimento ${ }^{86}$, deve-se questionar se é possível reconhecer alguém apenas pelo modo de andar e de se vestir, independentemente do fato de estar de costas.

Surge, então, outro importante questionamento, útil na perspectiva do controle epistemológico desse meio de prova: quando e sob que condições é necessário que a testemunha esclareça os critérios com base nos quais identificou o suspeito?

Até aqui, as reflexões empreendidas tiveram a preocupação de aferir a eficácia probatória do reconhecimento por vídeo de vigilância, sem, ainda, aludir a limites probatórios de ordem não epistemológica. Nesse ponto, também, há indagações de extrema relevância: em que medida a adoção de critérios notoriamente preconceituosos na identificação podem violar os direitos do réu? A depender do grau de contaminação psicológica do sujeito que reconhece, é possível afirmar a inadmissibilidade da prova? Ou a questão deve ser levada ao plano da valoração, atribuindo-se ao depoimento sobre o vídeo um baixo grau de demonstração? E, sob esta última perspectiva, como poderia o standard probatório do processo penal - comumente referido como "prova além da dúvida razoável" - será alcançado, se a prova da autoria se fundamenta principal ou exclusivamente nesse reconhecimento?

A forma de apresentação do vídeo também é alvo de inquietação, seja sob a ótica epistemológica, seja na da proteção dos direitos fundamentais do réu. À luz dessas perspectivas, pode-se questionar o fato de sentenças condenatórias serem fundamentadas na prova em vídeo quando esta tiver sido produzida e valorada a partir de fotografias nos autos. Nesses casos, perde-se, ainda, a dimensão emocional e fluida do vídeo.

A falta de preocupação com o tratamento do vídeo, e a simples análise a partir de fotografias de cenas específicas, como se se tratasse de um documento estático, prejudica o exercício do contraditório sobre a prova. Ainda, afirmações como as contidas no acórdão, no sentido de ser indiferente o fato de o vídeo não captar o rosto e de que isso não fragilizaria a prova em vídeo, parece violar o standard probatório mínimo exigido para o processo penal.

\footnotetext{
${ }^{86}$ Principalmente BURTON et. al., 1999, p. 246-247.
} 


\subsubsection{Segundo acórdão - reconhecimento por pessoa familiar}

O segundo acórdão também confirma uma sentença condenatória. Trata-se de furto, no período noturno, de quatro monitores de vídeo pertencentes a uma escola. Convidada por funcionários do colégio a assistir ao vídeo de segurança, a genitora do acusado reconheceu o filho nas imagens. $\mathrm{O}$ acusado exerceu o direito ao silêncio na fase do inquérito, e "em juízo, conquanto afirmasse não se lembrar dos fatos, posto que usuário de substâncias entorpecentes, afirmou que sua mãe o reconheceu após assistir ao vídeo de segurança do colégio vitimado $[\ldots]^{\prime 87}$

A referência ao depoimento da genitora do réu esclarece que ela foi "ouvida durante o inquérito", quando "confirmou que após suspeitas contra seu filho, foi convidada pela diretora a assistir ao vídeo de segurança do colégio, no qual já trabalhou na função de merendeira. Após verificar a filmagem, reconheceu Ricardo como sendo o rapaz que aparece." $" 88$

O voto do relator concluiu: "no caso em tela, porque a confissão do crime foi corroborada pelos testemunhos mencionados, ganhando relevo o reconhecimento perpetrado pela mãe do ora apelante, dessa compatibilidade restou certa a autoria delitiva." 89

Observa-se novamente que tanto o reconhecimento como o vídeo são apresentados no conjunto probatório de forma indireta, apesar de constituírem o principal, se não o único, ${ }^{90}$ fundamento probatório da condenação. Porém, desta vez, o reconhecimento ocorreu no próprio estabelecimento do fato criminoso e o depoimento da pessoa que reconhece o autor foi extraído na fase de inquérito.

87 SÃO PAULO. Tribunal de Justiça. Apelação Criminal 0002346-77.2013.8.26.0127. Relator: Des. Figueiredo Gonçalves. $1^{\text {a }}$ Câmara de Direito Criminal. São Paulo, 14 dez. 2015. Disponível em: http://esaj.tjsp.jus.br/cjsg/getArquivo.do?cdAcordao=9089935\&cdForo=0. Acesso em: 15 maio 2021.

88 Ibid.

${ }^{89}$ SÃO PAULO. Apelação Criminal 0002346-77.2013.8.26.0127, 2015, destacou-se.

90 No acórdão, o Relator menciona a confissão do acusado como fundamento probatório, ao lado do reconhecimento a partir do vídeo. Todavia, pela leitura do relatório está claro que o réu alega não se lembrar dos fatos. 
Não foram consideradas advertências sobre a preferência do reconhecimento presencial em relação ao reconhecimento por imagens e a valoração deste como mero indício. $^{91}$

Por fim, o acórdão não descreve o conteúdo do vídeo de vigilância ou faz qualquer referência sobre a qualidade das imagens.

\subsubsection{Terceiro acórdão - fragmentação do conteúdo do vídeo}

Trata-se de acórdão confirmatório de sentença condenatória por furto de carteira, filmado por sistema de vigilância residencial. Os policiais reconheceram o acusado ao visualizarem o conteúdo da gravação afirmando que é bastante conhecido no meio policial. Quanto ao procedimento realizado pelos policiais para abordar o suspeito, é relatado que houve fragmentação do conteúdo do vídeo. ${ }^{92}$

Nesse caso a prova de autoria é consubstanciada principalmente no reconhecimento por policiais a partir de vídeo de vigilância. O acórdão, entretanto, analisa o vídeo indiretamente a partir de declarações do ofendido e dos policiais, sendo o conteúdo do vídeo um dos principais fundamentos da condenação. O que se conhece do vídeo é apenas o que foi relatado por terceiros, não se sabe sequer se foi juntado aos autos.

Ademais, não há informações sobre o procedimento realizado para fragmentar o vídeo, o que seria aconselhável, diante do fato da possibilidade de se questionar a manipulação da imagem à luz da necessidade de preservação da cadeia de custódia da prova.

\footnotetext{
${ }^{91}$ DEAN, 1989, p. 826-842; LOPES, 2011, p. 29; 180.

${ }^{92}$ Como se vê do depoimento de policial: "Que ao questionar [...] sobre o furto praticado, tendo exibido um primeiro vídeo em que um indivíduo estava caminhado no endereço do fato, [...] confirmou que o referido indivíduo é ele; que no segundo vídeo em que o mesmo indivíduo aproximou-se do veículo, abriu a porta e subtraiu a carteira da vítima, onde continha a quantia de $\mathrm{R} \$ 1200,00$ (hum mil e duzentos reais), este desconversou dizendo não ser ele; que deslocaram até a residência do autor, onde foi encontrado a camisa usada por ele na prática delituosa, a qual foi recolhida; que o autor recusou a informar onde teria escondido os materiais do furto". (MINAS GERAIS. Tribunal de Justiça. Apelação Criminal 1.0261.18.011994-1/001. Relator: Des. Octavio Augusto de Nigris Boccalini. 3ª Câmara Criminal. Belo Horizonte, 25 jun. 2019. Disponível FE09E9217EB67219DE39.juri_node1?numeroRegistro=1\&totalLinhas=1\&linhasPorPagina=10\&numeroUn ico=1.0261.18.011994-1\%2F001\&pesquisaNumeroCNJ=Pesquisar. Acesso em: 5 jun. 2021.).
} 


\subsubsection{Quarto acórdão - laudo pericial pela impossibilidade de reconhecimento}

O quarto e último acórdão reforma sentença condenatória por furto de veículo em via pública, filmado por câmera de vídeo de estabelecimento comercial. A vítima afirmou que viu as imagens e pôde reconhecer o acusado como a pessoa que entrou no automóvel e furtou. No mesmo sentido, o policial afirmou ter visto o acusado na via pública "em atitude suspeita, perto do estabelecimento policial". Mais tarde, quando foi informado o furto na Delegacia de Polícia, o mesmo policial "assistiu à filmagem e reconheceu o acusado como a pessoa que aparece na imagem ali retratada". ${ }^{93}$

As imagens aqui referidas no depoimento foram analisadas pelo laudo pericial, cujo conteúdo serviu de base ao acórdão absolutório. ${ }^{94}$

As imagens fragmentárias foram provavelmente completadas pela suspeita do policial, o que levou à condenação do réu em primeiro grau - ainda que o laudo pericial afirmasse não ser possível o reconhecimento. Isso se alinha com a tendência já mencionada aqui e reportada pela literatura ${ }^{95}$. Somente em segundo grau se deu a absolvição.

Ainda, curiosamente, o vídeo não foi juntado aos autos, somente o laudo pericial e as fotografias de frames da gravação. O laudo contrasta com as percepções das testemunhas sobre o vídeo, demonstrando a subjetividade da imagem. Observa-se, também, como nos casos precedentes, a falta de procedimento e ritualidade. O reconhecimento a partir do vídeo se transformou em testemunhos e prova pericial, assim como documental, em razão das fotografias juntadas.

93 SÃO PAULO. Tribunal de Justiça. Apelação Criminal 0000643-56.2010.8.26.0438. Relator: Des. Marco de Lorenzi. 14 ${ }^{\mathrm{a}}$ Câmara Criminal. São Paulo, 27 nov. 2014. Disponível em: http://esaj.tjsp.jus.br/cjsg/getArquivo.do?cdAcordao=8066409\&cdForo=0. Acesso em: 5 jun. 2021.

94 "O elemento indiciário que poderia conectar o réu à subtração é a filmagem do estabelecimento comercial no qual ele mesmo admitiu ter entrado, circunstância confirmada pela testemunha Antônio.

Contudo, tal indício não é suficiente para a comprovação da subtração do automóvel, pois do laudo de fls. 06/10, em que o perito policial expõe suas conclusões acerca das imagens ali captadas, não se vê qualquer indicativo da subtração do veículo.

Nas fotografias retratadas a fls. 07 e 08, bem como nas duas primeiras fotografias de fls. 09, é possível ver o acusado entrando e saindo do estabelecimento, sem se aproximar de qualquer veículo estacionado. As duas últimas imagens de fls. 09 mostram o veículo subtraído sendo conduzido na via pública, sem possibilidade de identificar o condutor. Ou seja, não há qualquer elemento de ligação entre o acusado e o carro furtado, pelo que se vê do referido laudo." (ibid., grifou-se)

${ }^{95}$ PORTER, 2014, p. 1753. 


\section{CONSIDERAÇÕES FINAIS}

A partir do objetivo geral de investigar o uso de vídeos de vigilância para o reconhecimento de pessoa no processo penal brasileiro, constatou-se da análise normativa e bibliográfica: 1. A inexistência de regulação legislativa específica que apresente ritual adequado à prova de autoria a partir de vídeo de vigilância. 2. A inadequação do ritual existente de reconhecimento presencial de pessoas previsto nos artigos 226 a 228 do CPP a ser utilizado como procedimento adequado correlato ao reconhecimento de pessoas a partir de vídeo de vigilância. 3. Até o momento, a não evolução de pesquisas e estudos ao ponto de indicar parâmetros epistêmicos a consolidar um ritual adequado ao reconhecimento de pessoas a partir de vídeo de vigilância no processo penal brasileiro.

Entende-se, então, a partir do exposto, que o reconhecimento por vídeo de segurança deve, no mínimo, submeter-se ao contraditório diferido, com a exibição do vídeo em audiência, a possibilidade de provas orais e periciais sobre o conteúdo da mídia e, inclusive, sobre a própria credibilidade e autenticidade do vídeo. Tal submissão ao contraditório diferido deverá ser realizado não como ato repetitório, mas sim como um momento que possibilite a refutação da identificação realizada em sede investigatória.

$\mathrm{Na}$ implementação deste contraditório, deve-se levar em conta que o vídeo possui características próprias. O procedimento de produção da prova documental não considera tais especificidades: as formas de armazenamento e análise do vídeo são distintas do documento físico e estático; não basta sua juntada aos autos para que seja produzido; a interpretação da imagem exige preparo técnico específico, assim como o exame de autenticação.

A partir da pesquisa empírica, vislumbrou-se: 1. A inexistência de uniformidade procedimental de realização do reconhecimento a partir do vídeo, constatando fragmentações do arquivo e falta de informação se o vídeo foi juntado aos autos, assim como a inexistência de depoimento em juízo da pessoa reconhecedora. 2. Uma valoração judicial que trata a imagem como retrato fiel da realidade, inclusive se manifestando no sentido de ser possível reconhecer sem que o rosto do agente a ser reconhecido fosse filmado. 
Assim, é possível responder aos questionamentos propostos: há, na legislação brasileira, procedimento relativo ao reconhecimento criminal de pessoas a partir de vídeo de vigilância? Qual é o procedimento utilizado na práxis judiciária? As respostas, conforme já indicado, são no sentido de inexistir um procedimento regulado legislativamente ao reconhecimento criminal de pessoas a partir de vídeo de vigilância; e da não identificação de um procedimento uniforme realizado na realidade, realizado em cada caso à sua maneira.

\section{REFERÊNCIAS:}

BADARÓ, Gustavo Henrique. Epistemologia judiciária e prova penal. São Paulo: Thomson Reuters Brasil, 2019.

BADARÓ, Gustavo Henrique. Processo penal. 8. ed. São Paulo: RT, 2020.

BOIVIN, Rèmi et al. The body-worn camera perspective bias. Journal of Experimental Criminology, 13, p. 125-142, 2017.

BRASIL. Superior Tribunal de Justiça. Agravo Regimental no Agravo Regimental no Agravo em Recurso Especial 1585502/SP. Relator: Min. Joel Ilan Paciornik. $5^{\text {a }}$ Turma. Brasília, 06 fev. 2020. Disponível em: https://bit.ly/2ZEodkZ. Acesso em: 15 maio 2021.

BRASIL. Superior Tribunal de Justiça. Agravo Regimental no Agravo em Recurso Especial 1665453/SP. Relator: Min. Joel Ilan Paciornik. 5 ${ }^{\text {a }}$ Turma. Brasília, 02 jun. 2020. Disponível em: https://bit.ly/2RqQB5R. Acesso em: 15 maio 2021.

BRASIL. Superior Tribunal de Justiça. Agravo Regimental no Habeas Corpus 525027/SP. Relator: Min. Reynaldo Soares da Fonseca. 5a Turma. Brasília, 21 nov. 2019. Disponível em: https://bit.ly/2RtaVU3. Acesso em: 15 maio 2021.

BRASIL. Superior Tribunal de Justiça. Habeas Corpus 598.886/SC. Voto do Relator Min. Rogerio Schietti Cruz. $6^{\mathrm{a}}$ Turma. Brasília, 27 out. 2020. Disponível em: https://bit.ly/2G6B496. Acesso em: 28 maio 2021.

BRASIL. Superior Tribunal de Justiça. Habeas Corpus 652.284/SC. Relator: Min. Min. Reynaldo Soares da Fonseca. 5 ${ }^{a}$ Turma. Brasília, 27/04/2021. Disponível em: https://scon.stj.jus.br/SCON/GetInteiroTeorDoAcordao?num_registro=202100769343\&dt_ publicacao=03/05/2021. Acesso em: 08 maio 2021. 
BRASIL. Superior Tribunal de Justiça. Recurso em Habeas Corpus 133.408/SC. Relator: Min. Sebastião Reis Júnior, 6a Turma. Brasília, 15 dez. 2020. Disponível em: https://scon.stj.jus.br/SCON/GetInteiroTeorDoAcordao?num_registro=2020021757 90\&dt_publicacao=18/12/2020. Acesso em: 14 jul. 2021.

BRUCE, Vicki et al. Verification of face identities from images captured on video. Journal of Experimental Psychology, vol. 5, n. 4, p. 339-360, 1999.

BURTON, A. Mike et al. Face recognition in poor-quality video: evidence from security surveillance. Psychological Science, vol. 10, n. 3, p. 243-248, maio 1999.

CÂMARA DOS DEPUTADOS. Ministério da Justiça quer unificar dados estaduais em grande banco de segurança pública. Disponível em: https://www.camara.leg.br/noticias/555649-ministerio-da-justica-quer-unificardados-estaduais-em-grande-banco-de-seguranca-publica/. Acesso em: 9 abr. 2020 Publicado em: 15 abr. 2019.

CECCONELLO, William Weber; AVILA, Gustavo Noronha; STEIN, Lilian Milnitsky. A (ir)repetibilidade da prova penal dependente da memória: uma discussão com base na psicologia do testemunho. Revista Brasileira de Políticas Públicas, [s. 1.], vol. 8, n. 2, p. 1057-1073, 2018.

CECCONELLO, William Weber; STEIN, Lilian Milnitsky; ÁVILA, Gustavo Noronha. Novos rumos para o reconhecimento de pessoas no Brasil? Perspectivas da psicologia do testemunho frente à decisão do HC 598.886-SC. Revista brasileira de ciências criminais. vol. 177, mar. 2021, p. 359-368, 2021.

CECCONELLO, William Weber; STEIN, Lilian Milnitsky. Prevenindo injustiças: como a psicologia do testemunho pode ajudar a compreender e prevenir o falso reconhecimento de suspeitos. Avances en Psicologia Latinoamericana, Bogotá, vol. 38 (1), p. 172-188, 2020.

CONVERGÊNCIA DIGITAL. Reconhecimento facial protagoniza segurança na Copa América. Disponível em: https://www.convergenciadigital.com.br/cgi/cgilua.exe/sys/start.htm?UserActiveTe mplate $=$ site $\&$ UserActiveTemplate $=$ mobile $\% 252$ Csite $\&$ infoid $=50977 \&$ sid $=18$. Acesso em: 24 nov. 2019. Publicado em: 14 jun. 2019. 
DAVIS, Josh P.; VALENTINE, Tim. CCTV on trial: matching video images with the defendant in the dock. Applied Cognitive Psychology, vol. 23, p. 482-505, maio 2009.

DEAN, Giovanni. In tema di 'libertà' e 'tassatività' delle forme nell'acquizione probatoria a proposito delle 'ricognizione fotografica'. Rivista italiana di diritto e procedura penale. Milano: Giuffrè, 1989, p. 826-842.

EDMOND, Gary; SAN ROQUE, Mehera. Justicia's gaze: surveillance, evidence and the criminal trial. Surveillance and Society, vol. 11, n. 3, p. 252-273, 2013.

EDMOND, Gary et. al. Law's looking glass: expert identification evidence derived from photographic and video images. Current Issues in Criminal Justice, vol. 20, n. 3, p. 337-377, mar. 2009.

ELMER, Greg. Panopticon - discipline - control. In: BALL, Kirstie at al. Routledge Handbook of Surveillance Studies. Oxon e Nova York: Routledge, 2012, p. 21-29.

FEIGENSON, Neil. Visual common sense. In: WAGNER, Anne; SHERWIN, Richard (Org.). Law Culture and Visual Studies. Dordrecht, Heidelberg, New York and London: Springer, p. 105-124, 2014.

FERRER BELTRÁN, Jordi. La valoración racional de la prueba. Madrid, Barcelona, Buenos Aires: Marcial Pons, 2007.

FITZGERALD, Ryan J.; PRICE, Heather L.; VALENTINE, Tim. Eyewitness identification: live, photo, and video lineups. Psychologic, Public Policy, and Law, vol. 24, n. 3, p. 307-325, 2018.

GATES, Kelly. The cultural labor of surveillance: video forensics, computational objectivity, and the production of visual evidence. Social Semiotics, Londres, vol. 23, n. 2, p. 242-260, 2013.

GUEDES, Clarissa Diniz. Persuasão racional e limitações probatórias: enfoque comparativo entre os processos civil e penal. Tese de doutorado. Orientador: José Rogério Cruz e Tucci. USP: São Paulo, 2013.

HENDERSON, Jennifer et al. An officer told George Floyd it took 'a lot of oxygen to talk,' body camera transcripts show. Disponível em: https://edition.cnn.com/2020/07/08/us/george-floyd-police-body-cameratranscripts/index.html. Acesso em: 14 jul. 2020. Publicado em: 9 jul. 2020. 
HORRY, Ruth et al. Predictors of eyewitness identification decisions from video lineups in England: a field study. Law and Human Behavior, vol. 36, n. 4, p. 257-265, 2012.

INNOCENCE PROJECT. Eyewitness identification reform. Disponível em: https://www.innocenceproject.org/eyewitness-identification-reform/. Acesso em: 28 maio 2021.

JAUCHEN, Eduardo M. Tratado de la prueba en material penal. Santa Fe: RubinzalCulzoni, 2009.

JENKINS, R.; BURTON, A. M. Limitations in facial identification: the evidence. Justice of the Peace, vol. 172, p. 4-6, jan. 2008.

LASSITER, G. Daniel; IRVINE, Audrey A. Videotaped confessions: the impact of camera point of view on judgments of coercion. Journal of Applied Social Psychology, vol. 16, n. 3, p. 268-276, 1986.

LARONGA, Antonio. Le prove atipiche nel processo penale. Padova: CEDAM, 2002.

LOPES JR., Aury. Direito processual penal. 14 ed. São Paulo: Saraiva, 2017.

LOPES, Mariângela Tomé. O reconhecimento como meio de prova: necessidade de reformulação do direito brasileiro. Tese de doutorado. Orientador: Antonio Scarance Fernandes. USP: São Paulo, 2011.

MATIDA, Janaína Roland. Standards de prova: a modéstia necessária a juízes e o abandono da prova por convicção. In: CALDAS, Diana Furtado et al. Arquivos da resistência: ensaios e anais do IV seminário nacional do IBADPP. 1 ed. Florianópolis: Tirant to blanch, 2019, p. 93-110.

MINAS GERAIS. Tribunal de Justiça. Apelação Criminal 1.0261.18.011994-1/001. Relator: Des. Octavio Augusto de Nigris Boccalini. $3^{\text {a }}$ Câmara Criminal. Belo Horizonte, 25 jun. $2019 . \quad$ Disponível em: https://www5.tjmg.jus.br/jurisprudencia/pesquisaNumeroCNJEspelhoAcordao.do;j sessionid=605659200087FE09E9217EB67219DE39.juri_node1 ?numeroRegistro= 1\&totalLinhas=1\&linhasPorPagina=10\&numeroUnico=1.0261.18.0119941\%2F001\&pesquisaNumeroCNJ=Pesquisar. Acesso em: 5 jun. 2021.

MINISTÉRIO DA JUSTIÇA; IPEA. Avanços científicos em psicologia do testemunho aplicados ao reconhecimento pessoal e aos depoimentos forenses. Brasília: Ministério da Justiça, Secretaria de Assuntos Legislativos (SAL); Ipea, 2015. 
PORTER, Elizabeth G. Taking images seriously. Columbia Law Review, vol. 114, p. 16871782, 2014.

PRADO, Geraldo. A cadeia de custódia da prova no processo penal. São Paulo: Marcial Pons, 2019.

ORWELL, George. 1984. Tradução de Alexandre Hubner e Heloísa Jahn. São Paulo: Companhia das Letras, 2009.

RICCIO, Vicente et al. Imagem e retórica na prova em vídeo. RIL, Brasília, a. 55, n. 220, p. 85-103, out./dez. 2018.

SÃO PAULO. Tribunal de Justiça. Apelação Criminal 0000643-56.2010.8.26.0438. Relator: Des. Marco de Lorenzi. 14a Câmara Criminal. São Paulo, 27 nov. 2014. Disponível

em: http://esaj.tjsp.jus.br/cjsg/getArquivo.do?cdAcordao=8066409\&cdForo=0. Acesso em: 5 jun. 2021.

SÃO PAUlO. Tribunal de Justiça. Apelação Criminal 0002346-77.2013.8.26.0127. Relator: Des. Figueiredo Gonçalves. $1^{\text {a }}$ Câmara de Direito Criminal. São Paulo, 14 dez. $2015 . \quad$ Disponível em: http://esaj.tjsp.jus.br/cjsg/getArquivo.do?cdAcordao=9089935\&cdForo=0. Acesso em: 15 maio 2021.

SÃO PAULO. Tribunal de Justiça. Apelação Criminal 0002525-58.2014.8.26.0294. Relator: Des. Otávio de Almeida Toledo. 16 Câmara Criminal. São Paulo, 05 jul. 2016 . http://esaj.tjsp.jus.br/cjsg/getArquivo.do?cdAcordao=9583836\&cdForo=0. Acesso em: 15 mar. 2021.

SHERWIN, Richard K. Visualizing law in the age of digital baroque: arabesques and entanglements. London and New York: Routledge, 2011.

SILBEY, Jessica. Cross-examining film. University of Maryland Law Journal of Race, Religion, Gender and Class, Baltimore, vol. 8, n. 1, artigo 4, p. 17-46, 2008.

SILBEY, Jessica. Persuasive visions: film and memory. Law, Culture and Humatinities, vol. 10, n. 1, p. 24-42, 2014.

TSIFOUTI, Anastasia et al. Acceptable bit-rates for human face identification from CCTV Imagery. SPIE Proceedings, vol. 8653, p. 1-15, fev. 2013. 
VIEIRA, Thiago. Aspectos técnicos e jurídicos da prova digital no processo penal. Disponível em: https://medium.com/@tocvieira/aspectos-t\%C3\%A9cnicos-ejur\%C3\%ADdicos-da-prova-digital-no-processo-penal-aa22ef05fb30\#_ftn15.

Acesso em: 27 maio 2021. Publicado em: 22 out. 2019.

WELLS, G.L. et. al. Eyewitness evidence: improving its probative value. Psychological Science in the Public Interest, vol. 7, n. 2, p. 45-75, 2006. 